\title{
Reproductive tract infections: A guide for programme managers
}

Sarah Hawkes

Anjali Nayyar

Johannes van Dam

Kevin R. O'Reilly

Bidia Deperthes

See next page for additional authors

Follow this and additional works at: https://knowledgecommons.popcouncil.org/departments_sbsr-rh

Part of the Demography, Population, and Ecology Commons, Infectious Disease Commons, and the International Public Health Commons

How does access to this work benefit you? Let us know!

\section{Recommended Citation}

Hawkes, Sarah, Anjali Nayyar, Johannes van Dam, Kevin R. O'Reilly, Bidia Deperthes, and Dinesh Agarwal. 2001. "Reproductive tract infections: A guide for programme managers." New Delhi: UNFPA and Population Council. 


\section{Authors}

Sarah Hawkes, Anjali Nayyar, Johannes van Dam, Kevin R. O'Reilly, Bidia Deperthes, and Dinesh Agarwal 


\title{
Reproductive Tract Infections: A Guide for Programme Managers
}

\author{
Sarah Hawkes ${ }^{1}$ \\ Anjali Nayyar ${ }^{1}$ \\ Johannes van Dam ${ }^{2}$ \\ Kevin O'Reilly ${ }^{3}$ \\ Bidia Deperthes ${ }^{3}$ \\ Dinesh Agarwal ${ }^{4}$
}

1 Population Council, South and East Asia Regional Office, New Delhi India

2 Population Council Horizons Programme, Washington DC, USA

3 World Health Organization, Geneva

4 United Nations Population Fund 


\section{What are Reproductive 'Tract Infections?}

Reproductive Tract Infections (RTIs) encompass three main groups of infection in men and women:

1. Endogenous infections of the female genital tract - such as candida or bacterial vaginosis.

2. Sexually transmitted infections (STIs) in both men and women.

3. Iatrogenic infections, acquired, for example, through unsterile procedures across the cervix, such as insertion of an intrauterine device, menstrual regulation or termination of a pregnancy.

There are over 30 identified organisms which can infect the reproductive tract. The most common organisms are listed in Box 1. Of the three types of RTIs, it is probably the endogenous infections (marked with an $*$ in Box 1 ), which are the most common infections in women. The sexually transmitted infections may have the greatest impact on both individuals (clinically and socially) and health-care systems dealing with management of infections (due to the cost of managing complications of the mis- or un-treated infections ).

In addition to the organisms named in Box 1, there are many others which can be transmitted sexually, but this is not the usual mode of transmission - Shigella and Entamoeba histolytica are examples of these. 
Box 1

Micro-organisms associated with sexual transmission or with infection in the reproductive tract

\begin{tabular}{|c|c|c|c|c|c|}
\hline Viruses & Bacteria & Protozoa & Mycoplasmas & Parasites & Fungi \\
\hline $\begin{array}{l}\text { Herpes } \\
\text { simplex } \\
\text { viruses }\end{array}$ & $\begin{array}{l}\text { Chlamydia } \\
\text { trachomatis }\end{array}$ & $\begin{array}{l}\text { Entamoeba } \\
\text { histolytica }\end{array}$ & $\begin{array}{l}\text { Ureaplasma } \\
\text { urealyticum }\end{array}$ & $\begin{array}{l}\text { Sarcoptes } \\
\text { scabiei }\end{array}$ & $\begin{array}{l}\text { Candida } \\
\text { albicans }^{*}\end{array}$ \\
\hline $\begin{array}{l}\text { Human } \\
\text { papilloma } \\
\text { virus }\end{array}$ & $\begin{array}{l}\text { Neisseria } \\
\text { gonorrboeae }\end{array}$ & $\begin{array}{l}\text { Trichomonas } \\
\text { vaginalis }\end{array}$ & $\begin{array}{l}\text { Mycoplasma } \\
\text { hominis* }\end{array}$ & $\begin{array}{l}\text { Phthirus } \\
\text { pubis }\end{array}$ & \\
\hline $\begin{array}{l}\text { Molluscum } \\
\text { contagiosum }\end{array}$ & $\begin{array}{l}\text { Gardnerella } \\
\text { vaginalis* }\end{array}$ & $\begin{array}{l}\text { Giardia } \\
\text { lamblia }\end{array}$ & & & \\
\hline $\begin{array}{l}\text { Hepatitis } \\
\text { viruses }\end{array}$ & $\begin{array}{l}\text { Treponema } \\
\text { pallidum }\end{array}$ & & & & \\
\hline $\begin{array}{l}\text { Cytomegalo- } \\
\text { virus }\end{array}$ & $\begin{array}{l}\text { Haemophilus } \\
\text { ducreyi }\end{array}$ & & & & \\
\hline $\begin{array}{l}\text { Human } \\
\text { immuno- } \\
\text { deficiency } \\
\text { viruses }\end{array}$ & $\begin{array}{l}\text { Ureaplasma } \\
\text { urealyticum }\end{array}$ & & & & \\
\hline $\begin{array}{l}\text { Human T } \\
\text { Lympho- } \\
\text { trophic } \\
\text { viruses }\end{array}$ & & & & & \\
\hline
\end{tabular}

\section{Points for Programme Managers}

Reproductive Tract Infections (RTIs) can be acquired in three ways: sexually, iatrogenically and from endogenous carriage. Control of each of these three types of infection will require different programmatic and strategic approaches. 


\section{Epidemiology of R'TIs/STIs}

\subsection{Epidemiology of R'TIs/STIs Globally}

Data on prevalence and incidence can be compiled both from published studies and from surveillance systems. In the case of RTIs/STIs, there is very little data on global incidence (but more information on prevalence), and longitudinal data from surveillance systems is limited to countries with an efficient and widespread system of reporting. As with most other disease categories, there is very little homogeneity in the published global prevalence of RTIs/STIs.

It is estimated that globally in 1995 there were approximately 333 million new cases of the 4 major curable STIs (gonorrhoea, chlamydia, syphilis, and trichomoniasis) in the 15-49 year old age group. Highest absolute numbers of new cases were found in the regions of south and south-east Asia, and sub-Saharan Africa - a reflection of both the global population distribution, and the higher recorded prevalence estimates for these regions. Individual regions may acknowledge specific STI problems - for example, the incidence of new syphilis infections in the former Soviet Union is reported to be increasing significantly.

\subsection{Epidemiology of RTIs/STIs in India}

India displays a remarkable level of heterogeneity in all aspects, and the epidemiology of RTIs/STIs is no exception. Such diversity is a reflection of the enormous size of the country, of the "phase" of the STI/HIV epidemic in any one place (rising, stable or declining), and of the highly variable broader contextual factors influencing prevalence and incidence rates 
Table 1

Published STI prevalence among men in India

\begin{tabular}{|c|c|c|c|c|c|c|c|c|c|}
\hline \multirow[b]{2}{*}{ Study population } & \multicolumn{9}{|c|}{ Prevalence ranges $(\%)$} \\
\hline & GC & CT & Syphilis & $\begin{array}{l}\text { Chancroid } \\
\text { (clinical } \\
\text { diagnosis) }\end{array}$ & TV & $\begin{array}{c}\text { HSV } \\
\text { (clinical } \\
\text { diagnosis) }\end{array}$ & $\begin{array}{c}\text { HPV } \\
\text { (clinical } \\
\text { diagnosis) }\end{array}$ & HbsAg & HIV \\
\hline $\begin{array}{l}\text { Community-based } \\
\text { or convenience } \\
\text { samples }\end{array}$ & & & & & & & & & \\
\hline $\begin{array}{l}\text { Males aged } \\
15-45 \text { years }\end{array}$ & 3.4 & 2.0 & 0.3 & - & - & - & - & 6.0 & 1.4 \\
\hline $\begin{array}{l}\text { Male participants } \\
\text { of a community } \\
\text { education } \\
\text { programme }\end{array}$ & 1.7 & 15.0 & - & - & 5.6 & - & - & - & 0.4 \\
\hline $\begin{array}{l}\text { Transport and } \\
\text { industrial workers }\end{array}$ & 2.1 & - & $0.8-4.4$ & - & - & - & - & - & - \\
\hline Facility-based & & & & & & & & & \\
\hline $\begin{array}{l}\text { STD clinic } \\
\text { patients }\end{array}$ & $\begin{array}{l}8.5- \\
25.9\end{array}$ & $\begin{array}{c}20.0- \\
30.0\end{array}$ & $\begin{array}{l}12.6- \\
57.0\end{array}$ & $16.1-34.7$ & - & $3.0-14.9$ & $4.9-14.3$ & - & $\begin{array}{l}2.0- \\
7.4\end{array}$ \\
\hline $\begin{array}{l}\text { STD clinic patients } \\
\text { with genital ulcers }\end{array}$ & - & - & - & 33.0 & - & - & - & - & - \\
\hline $\begin{array}{l}\text { Patients attending } \\
\text { primary health care }\end{array}$ & - & - & 3.6 & - & - & - & - & - & - \\
\hline $\begin{array}{l}\text { Specific groups } \\
\text { Spouses of females } \\
\text { with candida and } \\
\text { trichomonas }\end{array}$ & - & - & - & - & 60.6 & - & - & - & - \\
\hline
\end{tabular}

Notes on Tables: GC = Neisseria gonorrboeae; $\mathrm{CT}=$ Chlamydia trachomatis; $\mathrm{TV}=$ Trichomonas vaginalis; $\mathrm{HSV}=\mathrm{Herpes}$ Simplex Virus; $\mathrm{HPV}=$ Human Papilloma Virus; HbsAg = Hepatitis B surface Antigen; HIV = Human Immunodeficiency Virus

Source Table 1\& 2: Hawkes S; and Santhya KG; 2001. Diverse Realities: Understanding STIs and HIV in India. Regional Working Paper No. 15. New Delhi: Population Council 
Table 2

\section{Published STI prevalence among women in India}

\begin{tabular}{|c|c|c|c|c|c|c|c|c|c|c|}
\hline \multirow[b]{2}{*}{ Study population } & \multicolumn{10}{|c|}{ Prevalence ranges $(\%)$} \\
\hline & GC & CT & Syphilis & $\begin{array}{l}\text { Chancroid } \\
\text { (clinical } \\
\text { diagnosis) }\end{array}$ & TV & $\begin{array}{c}\text { HSV } \\
\text { (clinical } \\
\text { diagnosis) }\end{array}$ & \begin{tabular}{|c|} 
HPV \\
(clinical \\
diagnosis)
\end{tabular} & $\begin{array}{c}\text { Cervical } \\
\text { dysplasia }\end{array}$ & HBV & HIV \\
\hline Community-based & & & & & & & & & & \\
\hline $\begin{array}{l}\text { Ever/currently } \\
\text { married women }\end{array}$ & $\begin{array}{c}0.0- \\
4.2\end{array}$ & $\begin{array}{l}0.5- \\
28.7\end{array}$ & $0.2-8.8$ & - & $\begin{array}{l}4.3- \\
27.4\end{array}$ & - & 11.8 & $\begin{array}{c}3.8 \% \\
\text { Grade III } \\
\text { dysplasia }\end{array}$ & - & - \\
\hline $\begin{array}{l}\text { Unmarried \& } \\
\text { married women }\end{array}$ & $\begin{array}{c}0.3- \\
3.9\end{array}$ & 5.2 & $0.2-10.5$ & - & $\begin{array}{l}0.8- \\
14.0\end{array}$ & - & - & - & 4.8 & 2.0 \\
\hline $\begin{array}{l}\text { Facility-based and } \\
\text { convenience samples }\end{array}$ & & & & & & & & & & \\
\hline $\begin{array}{l}\text { STD clinic } \\
\text { patients }\end{array}$ & $\begin{array}{l}1.3- \\
10.4\end{array}$ & - & $\begin{array}{c}29.3- \\
43.3\end{array}$ & - & - & $4.0-15.4$ & $6.7-15.6$ & - & - & $\begin{array}{l}1.2- \\
13.6\end{array}$ \\
\hline Sex Workers & $\begin{array}{l}4.9- \\
16.5\end{array}$ & - & $\begin{array}{c}30.0- \\
63.0\end{array}$ & - & - & - & 0.5 & - & - & 49.9 \\
\hline Gynaecological & $1.0-$ & $0.2-$ & $4.4-5.6$ & - & $0.4-$ & $0.3-$ & $0.6-$ & $9.2 \%$ & - & 0.0 \\
\hline OPD patients & 5.5 & 31.3 & & & 26.0 & 25.0 & 42.4 & $\begin{array}{c}\text { severe } \\
\text { dyskaryosis } \\
5.4 \% \\
\text { invasive } \\
\text { carcinoma }\end{array}$ & & \\
\hline Antenatal patients & - & 2.3 & $\begin{array}{c}1.0- \\
6.2\end{array}$ & - & 17.8 & - & - & - & - & $\begin{array}{c}0.1- \\
1.2\end{array}$ \\
\hline $\begin{array}{l}\text { Gynaecological } \\
\text { patients with } \\
\text { 'vaginitis' complaints }\end{array}$ & $\begin{array}{l}0.0- \\
2.6\end{array}$ & $\begin{array}{l}2.6- \\
12.2\end{array}$ & 2.2 & - & $\begin{array}{l}1.6- \\
17.6\end{array}$ & - & - & - & - & - \\
\hline $\begin{array}{l}\text { Gynaecological } \\
\text { patients with cervical } \\
\text { erosion }\end{array}$ & - & 3.0 & - & - & - & - & - & \begin{tabular}{|c|}
$1.6 \%$ \\
moderate \\
dysplasia \\
$13 \%$ \\
severe \\
dysplasia \\
$1.8 \%$ \\
malignant
\end{tabular} & & \\
\hline $\begin{array}{l}\text { Infertility and PID } \\
\text { patients }\end{array}$ & $\begin{array}{l}0.1- \\
11.0\end{array}$ & $\begin{array}{l}0.5- \\
24.2\end{array}$ & 0.5 & - & 0.5 & - & - & - & - & - \\
\hline $\begin{array}{l}\text { Acceptors of tubal } \\
\text { ligation }\end{array}$ & $\begin{array}{c}0.1- \\
2.2\end{array}$ & $\begin{array}{c}0.0- \\
0.2\end{array}$ & $0.5-7.0$ & - & 0.9 & - & - & - & - & - \\
\hline
\end{tabular}

Notes on Tables: GC = Neisseria gonorrhoeae; CT = Chlamydia trachomatis; TV = Trichomonas vaginalis; HSV = Herpes Simplex Virus; $\mathrm{HPV}=$ Human Papilloma Virus; HbsAg = Hepatitis B surface Antigen; HIV = Human Immunodeficiency Virus 
There is often

a lack of

standardisation in

laboratory criteria

used in each

study - this can

influence

prevalence

reported and the ability of the health care system to record and respond to these rates. In the absence of a fully functioning STI surveillance system, predictions and estimates are made on the basis of ad-hoc surveys, often among facility-based or convenience samples. Tables1 \& 2 provide summaries of the results of published cross-sectional surveys on STI prevalence in India.

\subsection{Epidemiological Diversity in India}

It is important to consider reasons contributing to the epidemiological diversity reported within Indian studies; these include:

i. The size of the country. As noted above, in a country as large as India, there are wide variations influencing the risks and vulnerabilities of different populations to STIs (including HIV). Thus, the wide variation in reported prevalence may be a reflection of the 'true' epidemiological diversity;

ii. Studies are carried out among people with different levels of risk - some studies focus on people in the 'general population' (often loosely defined), whilst others concentrate on 'risk groups'. It is clearly important to know who is included in survey results, and exact criteria for inclusion should be clearly defined.

iii. There is often a lack of standardisation in laboratory criteria used in each study - this can influence prevalence reported. In the case of syphilis, for example, some studies report all rapid plasma reagin (RPR - a screening test for syphilis) positive cases, whilst others report only those confirmed by Treponema pallidum haemagglutination assay (TPHA). Diagnosis of other pathogens, such as Chlamydia trachomatis, shows an even wider variation in methods and standards 
used. In many studies the laboratory methods used are either inadequately explained or are not detailed at all.

Retaining this critical perspective on the published data is important for both understanding the current reported figures, and for designing future research and control programmes. A close review of the published epidemiology in India highlights the following points:

- Data on STI prevalence in men are lacking, especially men in the 'general population'. The majority of facility-based and community-based studies have focused on examining STI rates in women and even here the data are relatively patchy and certainly incomplete, given the size of the population.

- There are wide variations in both the reported prevalence of syphilis and diagnostic criteria used. The high prevalence of syphilis (ranging from $<1 \%$ to $10 \%$ in some communitybased surveys) among women in some parts of the country is in little doubt (see Table 2 for details). Despite this, prevention of mother-to-child transmission of syphilis (through antenatal screening of all pregnant women) is unevenly implemented throughout the country.

- Relatively little research has been carried out on the epidemiology of the viral infections (apart from HIV). Hepatitis B infection is believed to be mainly transmitted from mother-to-child or during childhood. Recent studies have found an average estimated carrier rate of $4 \%$ in the general population, and researchers have recommended universal immunization of neonates as the appropriate strategy for India. The prevalence of genital herpes in the general male and female population has not been explored in any of the community based studies. In addition, there are no community-based studies on the prevalence of antibodies 
to HSV-2 - an important virus which is believed to be both a marker of lifetime sexual activity and risk, and possibly linked to the risk of HIV transmission.

- Cervical cancer contributes significantly to the burden of morbidity and mortality in Indian women with an estimated 90,000 new cervical cancer cases arising annually. Despite this, little data exist either on the prevalence of different types of cervical dysplasia among women, or on the number of women (and men) infected with human papilloma virus (HPV). Only one community-based study among women in a Delhi slum has reported on the prevalence of HPV subtypes and prevalence of cervical dysplasia is similarly little understood.

\section{Points for Programme Managers}

India is characterised by epidemiological diversity in terms of STI/ RTI rates. Results from one part of the country cannot necessarily be extrapolated to other areas. There are, nonetheless, nation-wide data gaps and nation-wide priorities which can be identified: information on men is lacking and we have very little information on most of the viral STIs in both men and women. Screening pregnant women for syphilis should be implemented nationally; there should be universal coverage of neonates for hepatitis B immunisation; and other programme priorities and interventions should be tailored to the local epidemiology and aetiology. 


\section{Why Aim to Control Reproductive Tract Infections and Sexually Transmitted Infections?}

The public health importance of RTIs can be seen from a number of [interlinked] perspectives ranging from their close association with HIV transmission, through to their economic consequences for both the infected/affected individuals and the overall health care system. The public health salience of RTIs has increased significantly in recent years, in part as more research highlights the extent of both the diseases and their complications. Given the prevailing gender disparities in all fields of life, women in India are and will be disproportionately affected by the risk of STI transmission. In addition, women are significantly more susceptible to the non-sexually transmitted RTIs. Public health programmes need to be cognisant of these increased risks for women in order to target resources in a gender-equitable way.

The importance of RTIs is illustrated through the following perspectives:

\section{Biological}

Improved management of STIs can lead to a significant decrease in HIV incidence. In those parts of India, which are at the perceived early or middle stages of an HIV epidemic, the contribution of STI control to curbing the spread of HIV may be significant. 
There has been a programme-level shift away from vertical family planning services and towards the provision of comprehensive integrated reproductive health $(\mathrm{RH})$ care at all levels of health sectors

\section{Political}

Recommendations from the 1994 United Nations International Conference on Population and Development (ICPD) stated that: "All countries should strive to make accessible through the PHC [primary health care] system, reproductive health to all individuals of appropriate ages... [this] should include ...treatment of reproductive tract infections; sexually transmitted diseases and other reproductive health conditions." Following the ICPD there has been a great deal of commitment to move away from demographic targets and towards a broader focus on human welfare, individual choice and the goals of gender equality. As a result, there has been a programme-level shift away from vertical family planning services and towards the provision of comprehensive integrated reproductive health $\mathrm{RH})$ care at all levels of health sectors. The Government of India, for example, has stated that the principles guiding reproductive health service delivery are that they should be 'client centred, demand driven, high quality, integrated services'.

\section{Economic}

The importance of RTIs/STIs from a public health perspective has increased with the recognition that the economic and logistical consequences for health care systems seeking to implement effective prevention and care activities for these infections can be significant. A 1993 report showed that the burden of STIs in many urban (high prevalence) populations in low income countries, as measured by disability-adjusted healthy life years lost, is a substantial fraction of the entire disease burden of those populations. RTIs are important not just in their acute presentation, but also because of their associated sequelae including: chronic pain, tubal scarring, ectopic pregnancy, infertility, poor outcomes of pregnancy, and associated morbidities and mortalities in neonates and infants. 
Not only are RTIs/STIs a significant potential drain on public sector health care resources, they also contribute substantially to the patterns of health care expenditure at the household level. A recent survey of 1100 randomly selected households in and around the city of Udaipur investigated expenditure on reproductive and child health $(\mathrm{RCH})$ care. RTI services constituted the top expenditure for households in their purchase of all types of RCH care. In other words, families surveyed in Rajasthan spent more of their own money on seeking care for symptoms of RTIs than they spent on child health care, and all forms of safe motherhood (pre- and post-natal, obstetric and abortion services).

\section{Points for Programme Managers}

RTIs are important from a number of perspectives, not least of which is their salient position on public health agendas - arising in part from their association with increased HIV transmission. In addition, they have important economic consequences for public health systems and individual sufferers. 


\section{Clinical Presentation of R'TIs}

As with most clinical symptoms and signs, RTIs can present in a variety of ways. Nonetheless, there are some presentations which are found more commonly, and these are shown in Box 2. These have been grouped into seven main syndromes - the importance of this classification is detailed on page 19.

\subsection{Main Clinical Complications of R'TIs}

As detailed above, RTIs are important from a number of public

RTIs are important from a number of public health perspectives: economic, biological, and political health perspectives: economic, biological, and political. Much of the importance of RTIs arises as a result of the complications and sequelae of mis- or un-treated infections. These complications include:

- Problems in pregnancy - foetal wastage, premature births, congenital infections; ectopic pregnancy (life-threatening in some women)

- Problems in neonates and infants - blindness, pneumonia, congenital syphilis

- Problems in infected sexually active men and women chronic pain, lifelong infection, infertility, neoplasias (genital cancers, Kaposis sarcoma, liver cancer), increased transmission of HIV.

\section{Points for Programme Managers}

There are over 30 types of organisms which can either infect the reproductive tract and/or can be transmitted sexually. Most of these organisms have the potential for serious complications in the individual sufferer - including transmission during pregnancy or at birth resulting in neonatal death or illness. 
Box 2

Aetiological agents causing common syndromes in the reproductive tract

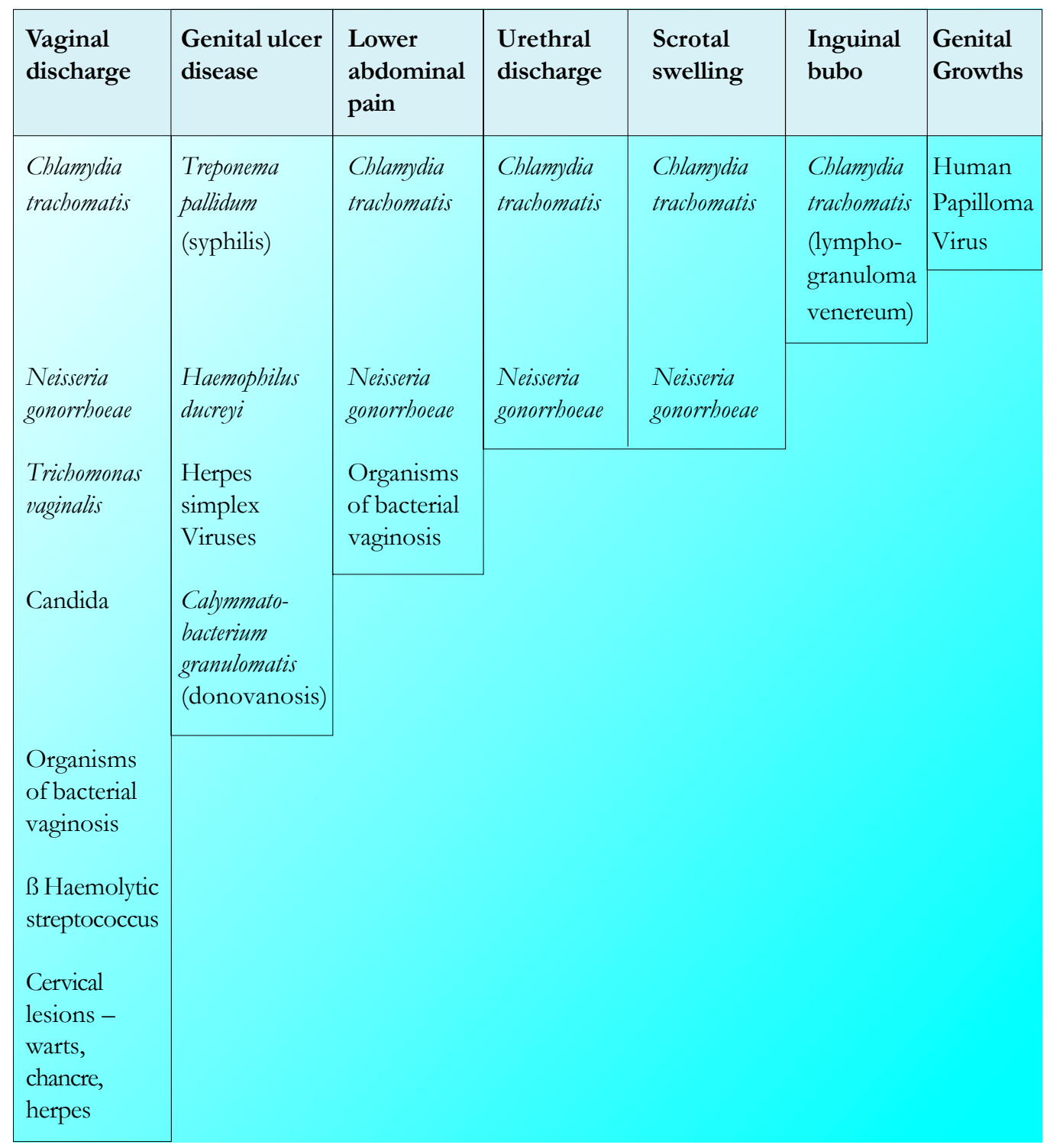




\section{The Diagnosis of R'TIs}

\section{Laboratory Diagnosis}

This is both the most accurate and, generally, the most costly approach to diagnosis. The depth and scale of laboratory testing can be adapted for appropriate use at different levels of a health care service (see Table 3); but it is important to recognise that even the most basic testing and diagnostic procedures (such as Gram stain or wet mount) are contingent upon the availability

The depth and scale of

laboratory testing can be adapted for appropriate use at different levels of a health care service of trained personnel and ongoing adequate supplies of reagents and/or infrastructure (such as a microscope, electricity supply, etc.).

\section{What is an "ideal laboratory test"?}

To judge whether a diagnostic test should be introduced at a particular level of health care, the following criteria must be taken into account:

- Sensitivity of the test (proportion of true positives identified)

- Specificity of the test (proportion of true negatives identified)

- Cost (to both the patient and the health system)

- Feasibility (for both the laboratory and the health system. Includes logistics, personnel, training, etc. requirements)

- Acceptability of the test (a test which involves the use of hard-toobtain samples may be unacceptable to the affected individual)

- Reliability (repeated tests on the same sample produce the same result)

- Availability (tests which are only available in specialised settings are clearly not recommended for use throughout the health system)

\section{Clinical Diagnosis}

This relies on the individual health-care worker making a diagnosis after clinical examination. Studies have shown that 
this form of diagnosis generally has a low sensitivity and specificity when compared to 'gold standard' laboratory tests*. The reasons for this are:

- low specificity of clinical symptoms and signs

- inaccurate interpretation of normal clinical features and signs, especially in the female genital tract

- occurrence of mixed infections.

\section{Rapid Diagnostics}

In order to increase the value of case management strategies, rapid diagnostic testing for STIs has been suggested as one part of the solution. These rapid tests are simple testing procedures which are easy to use at all levels of the health care service and provide a test result at the point- and time-of-care. Although there are currently several test kits which are commercially available, there is very little information on the efficacy of their use in primary health care (PHC) settings, and little data on their effectiveness (sensitivity, specificity, etc) and utility in "real world" settings. Trials of these diagnostic kits are planned in the near future.

\section{The Role of the Laboratory}

Table 3 gives examples of the laboratory tests which may be carried out at different levels of the health system. It will be seen that not every organism can be diagnosed even at basic levels of health care, and some require full-scale laboratory facilities for diagnosis (e.g the laboratory diagnosis of Haemophilus ducreyi is probably only possible in fully equipped settings). Programme managers should make decisions on diagnostic capabilities depending on a number of factors including: costs of diagnosis; cost of diagnosis per true case identified (if such information is available); laboratory facilities available; presence of trained staff; ability to maintain a regular supply of necessary laboratory equipment and supplies. In many

*Gold standard laboratory tests provide the highest level of sensitivity and specificity for the diagnosis of any named organism 
Table 3

\section{Recommended diagnostic tests by level of laboratory capability}

\begin{tabular}{|c|c|c|c|c|}
\hline Disease & Laboratory test & Peripheral & $\begin{array}{l}\text { Laboratory level } \\
\text { Intermediate }\end{array}$ & $\begin{array}{c}\text { Central/ } \\
\text { STD centre }\end{array}$ \\
\hline $\begin{array}{l}\text { Neisseria } \\
\text { gonorrboeae }\end{array}$ & $\begin{array}{l}\text { Smear (Gram, methylene } \\
\text { blue, safranin) } \\
\text { Culture } \\
\text { B-lactamase } \\
\text { Antimicrobial susceptibility } \\
\text { PCR }\end{array}$ & $\begin{array}{l}+ \\
- \\
- \\
- \\
-\end{array}$ & $\begin{array}{l}+ \\
+ \\
+ \\
+ \\
- \\
-\end{array}$ & $\begin{array}{l}+ \\
+ \\
+ \\
+ \\
+\end{array}$ \\
\hline $\begin{array}{l}\text { Chlamydia } \\
\text { trachomatis }\end{array}$ & $\begin{array}{l}\text { Antigen detection } \\
\text { DFA } \\
\text { ELISA } \\
\text { DNA hybridisation } \\
\text { Culture } \\
\text { Serology } \\
\text { PCR }\end{array}$ & $\begin{array}{l}- \\
- \\
- \\
- \\
- \\
-\end{array}$ & $\begin{array}{l}(+) \\
- \\
- \\
- \\
- \\
-\end{array}$ & $\begin{array}{l}+ \\
+ \\
+ \\
+ \\
+ \\
+ \\
+\end{array}$ \\
\hline Syphilis & $\begin{array}{l}\text { Darkfield microscopy } \\
\text { RPR } \\
\text { TPHA } \\
\text { FTA } \\
\text { IgM }\end{array}$ & $\begin{array}{l}- \\
(+) \\
- \\
- \\
-\end{array}$ & $\begin{array}{c}(+) \\
+ \\
(+) \\
- \\
-\end{array}$ & $\begin{array}{l}+ \\
+ \\
+ \\
+ \\
+\end{array}$ \\
\hline $\begin{array}{l}\text { Human } \\
\text { papilloma virus }\end{array}$ & $\begin{array}{l}\text { Cervical cytology } \\
\text { PCR }\end{array}$ & $\begin{array}{l}- \\
-\end{array}$ & $\begin{array}{l}- \\
-\end{array}$ & $\begin{array}{l}+ \\
+\end{array}$ \\
\hline Genital herpes & $\begin{array}{l}\text { Antigen detection } \\
\text { Culture } \\
\text { Serology } \\
\text { PCR }\end{array}$ & $\begin{array}{l}- \\
- \\
- \\
-\end{array}$ & $\begin{array}{l}- \\
- \\
- \\
-\end{array}$ & $\begin{array}{l}+ \\
+ \\
+\end{array}$ \\
\hline Chancroid & $\begin{array}{l}\text { Culture } \\
\text { Antimicrobial susceptibility } \\
\text { PCR }\end{array}$ & $\begin{array}{l}- \\
- \\
-\end{array}$ & $\begin{array}{l}- \\
- \\
-\end{array}$ & $\begin{array}{l}+ \\
+ \\
+\end{array}$ \\
\hline Donovanosis & $\begin{array}{l}\text { Smear (Leishman, Wright) } \\
\text { Histopathology }\end{array}$ & - & $\begin{array}{c}(+) \\
-\end{array}$ & $\begin{array}{l}+ \\
+\end{array}$ \\
\hline Trichomoniasis & $\begin{array}{l}\text { Wet mount microscopy } \\
\text { Culture }\end{array}$ & $\begin{array}{l}+ \\
-\end{array}$ & $\begin{array}{l}+ \\
- \\
\end{array}$ & $\begin{array}{l}+ \\
+\end{array}$ \\
\hline Candidiasis & $\begin{array}{l}\text { Wet mount }(\mathrm{cv} .+10 \% \mathrm{KOH}) \\
\text { Culture }\end{array}$ & $\begin{array}{l}+ \\
-\end{array}$ & $\begin{array}{l}+ \\
-\end{array}$ & $\begin{array}{l}+ \\
+\end{array}$ \\
\hline $\begin{array}{l}\text { Bacterial } \\
\text { vaginosis }\end{array}$ & $\begin{array}{l}\text { Wet mount, stained smear, } \\
\text { pH, KOH sniff test }\end{array}$ & + & + & + \\
\hline
\end{tabular}

+ Yes (+) yes, if possible - No

Source: Gina Dallabetta, Marie Laga, and Peter Lamptey(eds.) 1986. Control of Sexually Transmitted Diseases: A Handbook for the Design and Management of Programs. AIDSCAP/Family Health International, pp231. 
cases, one of the most pragmatic decisions to be made is the 'cost' of waiting for a laboratory result as against immediate treatment of a symptomatic client (will s/he return for the results; will further transmission occur whilst results are awaited?).

One of the most important roles of the microbiology laboratory in RTI/STI control programmes is as a facility for monitoring and evaluating activities - e.g. monitoring patterns of antibiotic susceptibility; and evaluating local case management strategies against gold standard laboratory results.

\section{Points for Programme Managers}

RTIs can be diagnosed according to a number of criteria: laboratory [aetiological diagnosis]; clinical; or syndromic. Choice of which criteria to use depends predominantly on the resources available at different levels of the health care system.
One of the most important roles of the microbiology laboratory in RTI/ STI control programmes is as a facility for monitoring and evaluating activities 


\section{Prevention and Care of R'TIs}

Prevention of RTIs encompasses various programmatic and individual level perspectives depending on whether control is aimed at the endogenous, sexually transmitted or iatrogenic infections. These issues are addressed in more detail in section 7. Nonetheless, for all types of infection, there are several common interventions which can be highlighted:

\subsection{Promoting Effective Health Care Seeking}

Interventions to change health care seeking behaviour aim to

One of the major challenges in India is to persuade symptomatic people to seek care from qualified practitioners change the following outcomes:

i. time taken to seek care if symptomatic

ii. numbers seeking care from a trained health care provider

iii. numbers persuading partners to seek care.

One of the major challenges in India is to persuade symptomatic people to seek care from qualified practitioners. Behavioural surveillance data from Tamil Nadu in the period 1996-2000 have shown a relatively consistent percentage of men who report symptoms of urethritis in the past year, but while the percent of symptomatic truckers who sought care from a qualified allopathic doctor has increased, it has correspondingly decreased among male factory workers and male students. Indeed, less than one-sixth of all symptomatic students had sought care from a qualified doctor. Such findings are corroborated in the NACO estimate that between only 5 and $10 \%$ of people with STIs seek care in the public sector.

\section{Points for Programme Managers}

Timely health care seeking from trained providers is the key for ensuring effective case management. Patterns of health seeking will change if people can be assured of high quality and effective treatment from providers. 


\subsection{Case Management of Symptomatic Individuals}

Traditionally, management of patients with RTIs/STIs has relied upon the results of laboratory tests or has been based upon the clinical judgment of the individual practitioner. As discussed above, in many settings these approaches may not be optimal and/or feasible. Recognising that in most resource poor settings there are no widespread laboratory facilities and there are relatively few trained STI/RTI specialists, the World Health Organization (WHO) has developed a set of management guidelines specifically for low-income, low-resource settings: syndromic management algorithms. The National AIDS Control Organization (NACO) has recommended syndromic management for case management, especially at the primary health care level.

The syndromic management approach relies on being able to identify and treat the clinical syndrome caused by an endogenous infection or STI. A syndrome is defined as the set of symptoms and/or signs that an individual suffers from and presents with in health-care settings. Among the many values of this approach is that it is relatively simple to use, and can be incorporated into all levels of the health care system - even at primary health care levels; and can be useful in both the public and private sectors. The syndromic approach recognises that there are several different organisms that can cause a particular set of symptoms or signs and recommends treatment for the most common group of aetiological agents which may be present. These syndromes and their common aetiologies were outlined in Box 2.

Studies have shown that the most common presenting symptom in female patients - vaginal discharge - is relatively poorly dealt with when using syndromic management. The lack of specificity of this symptom, and the difficulty interpreting clinical signs may mean that women are over-diagnosed and over-treated for 
The ability of health workers to adhere to the recommended clinical algorithms has been shown to be poor, especially in the case of vaginal discharge
STIs when they are in fact only suffering from endogenous infections. Conversely, the asymptomatic carriage of Neisseria gonorrhoeae and/or Chlamydia trachomatis can lead to a low sensitivity of the recommended algorithm, resulting in infected women not being treated.

An additional problem is that the ability of health workers to adhere to the recommended clinical algorithms has been shown to be poor, especially in the case of vaginal discharge.

However, trained and experienced clinicians have been shown to achieve a higher sensitivity for detecting cervical infections during clinical diagnosis, than other health workers. This carries clear implications for resource management and personnel placement in health-care programmes.

Behavioural risk assessment has been introduced to try and distinguish between those women with an STI as a cause of their symptoms, and those suffering from an endogenous infection. Evaluations of behavioural risk assessment have been carried out in several settings in sub-Saharan Africa, and elsewhere in the world, and have shown that the introduction of this step into the syndromic algorithm increases its specificity and positive predictive value, but sensitivity may remain a problem. Similarly, other researchers have found that performing internal gynaecological examinations can improve the performance of adapted algorithms.

Other evaluations of syndromic algorithms have shown that they can work well in the case of clients with genital ulcers and for symptomatic men with urethral discharge, and possibly for men with dysuria (pain passing urine) as their main symptom. It should be noted, however, that most evaluations have been undertaken in areas with a reasonably moderate to high prevalence of STIs.

A final note of caution: treatment for many of the organisms mentioned in Box 2 (aetiologies of common syndromes) is 
unlikely to be available at all levels of the health care system. For example, treatment of genital warts (either with drugs or, for example, cautery) is unlikely to be feasible in primary health care settings.

\section{Points for Programme Managers}

Global reviews of syndromic management have found that this approach works well for symptomatic men and for men and women with genital ulcers. For women with vaginal discharge, however, the algorithms must be adapted to the local epidemiology and aetiology, when this is known.

A study carried out in New Delhi among over 300 symptomatic women seeking care in a NGO reproductive health clinic reported a reasonably high STI prevalence: $22 \%$ of women had an STI (chlamydia, trichomonas or syphilis; none with gonorrhoea) diagnosed by the laboratory, including $12 \%$ with Chlamydia trachomatis. Syndromic flow charts performed well for the management of vaginal infections, but the STIs were poorly managed with only $5 \%$ of women infected with chlamydia receiving appropriate treatment.

\subsection{Partner Management}

Partner management is seen as a cornerstone of effective STI management. It is premised upon the fact that if only the "index patient" (that is, the client presenting for care) is treated, then s/ he is likely to be re-infected if her/his sexual partners are not simultaneously treated. By treating sexual partners of patients, whether symptomatic or not, re-infection can be halted and ongoing transmission curtailed. There are number of possible strategies for partner management:

- The patient contacts partners his/her self, and advises them to seek care;

- Provider management where providers obtain information
By treating sexual partners of patients, whether symptomatic or not, re-infection can be halted and ongoing transmission curtailed 


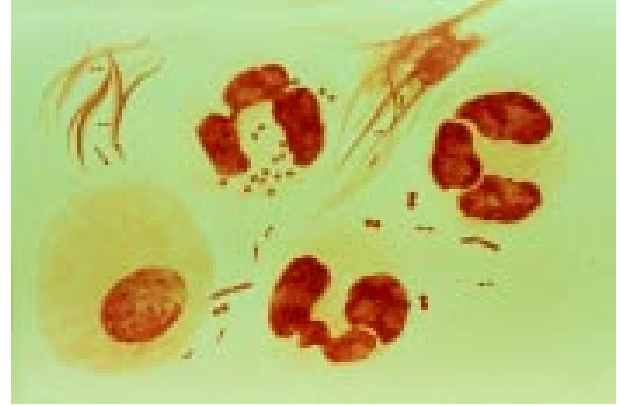

Gram smear showing Gram negative intracellular diplococci

- suggestive of gonorrhoea

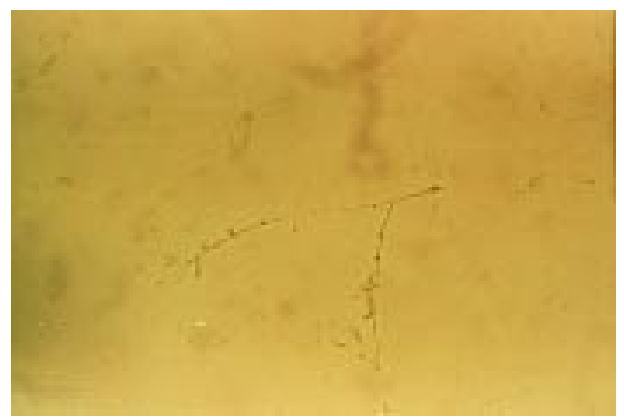

$\mathrm{KOH}$ wet mount with budding yeast cells-Candida specis

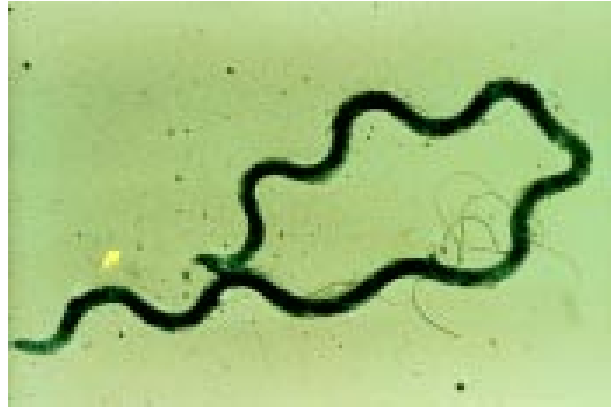

Treponema pallidum - causative organism of syphilis

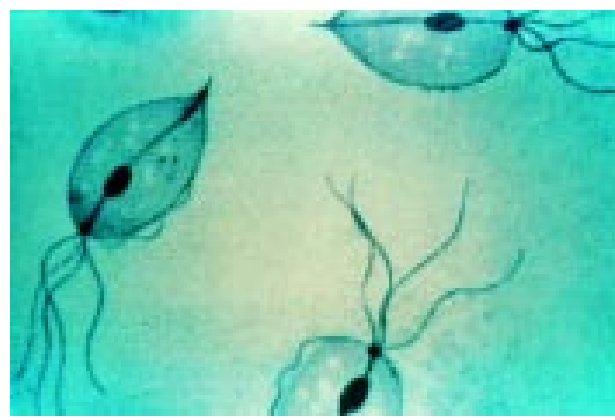

Saline wet mount with organisms of Trichomonas vaginalis

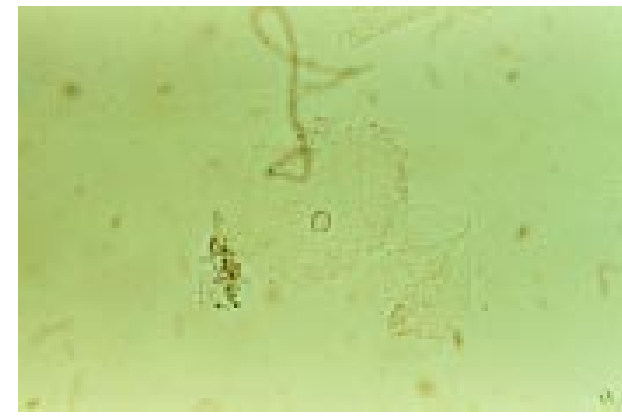

Epithelial cells covered with small bacteria - seen in bacterial vaginosis 


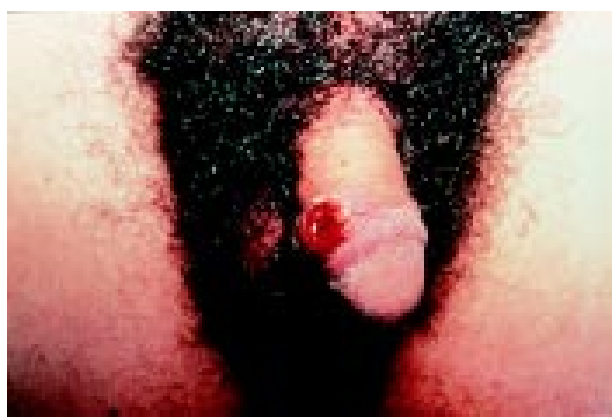

Lesion of primary syphilis

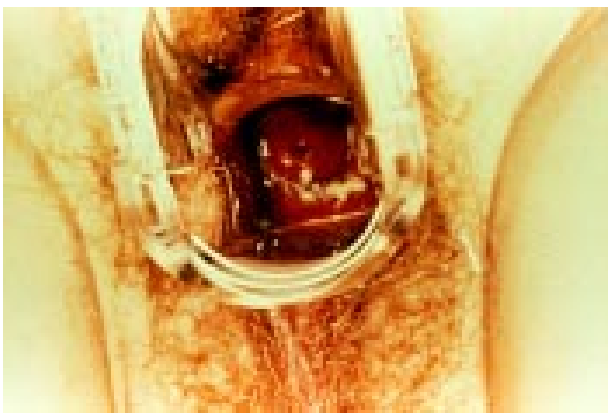

Clinical picture of candidiasis

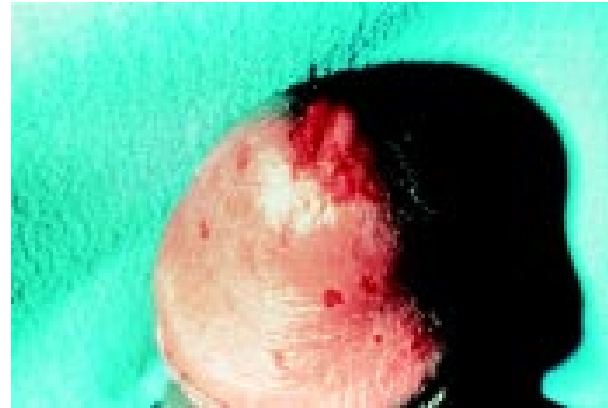

Lesions of genital herpes

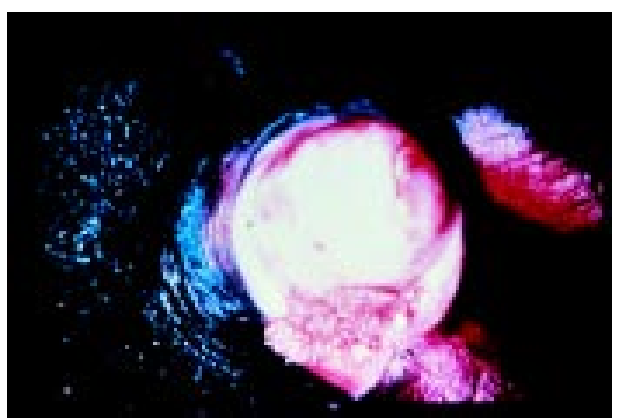

Genital warts

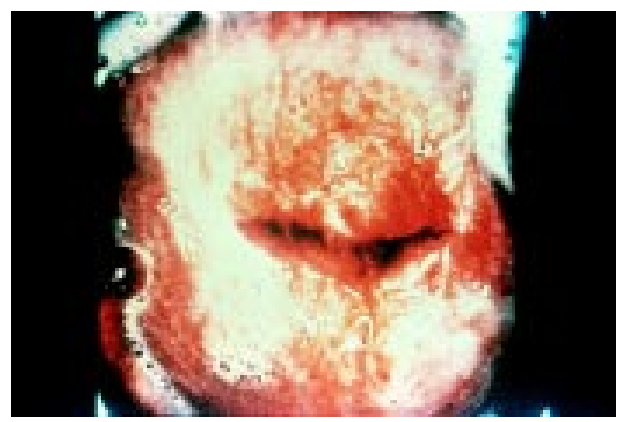

Discharge associated with

Trichomonas vaginalis infection 
In STD clinics in India, counselling for prevention is inadequate and poor from patients and contact the partners themselves (this is the most costly approach);

- Combination referral where a mixture of the above two methods is employed.

Partner management can be integrated into all settings where STI care is provided but studies in India have shown that this procedure is rarely discussed or initiated by health care providers. A clinic based study in Chennai, observed that advice on partner management was given during only $27 \%$ of the consultations. Likewise, a study in Delhi reported that none of the 100 male and female STD patients were advised about partner management. In a community-based study in rural Tamil Nadu, none of the symptomatic women and only $5.7 \%$ of the symptomatic men were advised to have their spouses examined for a possible infection.

\section{Points for Programme Managers}

Partner management (PM) is an essential component of STI control. The most acceptable and effective methods of PM should be evaluated for local population settings. Options include provider-led referral, client-led referral and combinations of the two.

\subsection{Counselling for Prevention}

The few studies on this issue in India have found that in STD clinics, counselling for prevention is inadequate and poor. Observations of STD consultations in Chennai revealed that advice of condom use for prevention of STDs was given during only $30 \%$ of the consultations. Instructions on how to use condoms were imparted to $6 \%$ of the clients and condoms were provided to $1 \%$. Similarly, in a study conducted in Tamil Nadu, only $15 \%$ and $28 \%$ of the symptomatic women and men respectively that had sought treatment from a health care facility were informed by the providers about the cause of their symptoms or the precautions to be taken to avoid the illness. 


\section{Points for Programme Managers}

STI counselling, including condom promotion, is an essential part of prevention and care activities for STI patients. Instructions on the correct use of condoms should be given, and condoms should be either distributed or sold, or advice given on where to obtain high quality, low cost condoms.

\subsection{Improving 'Treatment Adherence}

Not complying correctly with recommended and standard treatment guidelines for therapeutic regimens can be due to a number of factors, all of which can result in sub-optimal doses of the recommended regimens:

- Being given erroneous treatment advice by the health care worker

- Not understanding the treatment recommendations

- Not finishing the recommended drug course

This latter point often arises when people are prescribed long courses of antibiotics and only take part of the course because their symptoms regress after a few doses. Such is the path towards antimicrobial resistance. In order to reduce the likelihood of this outcome, there are a number of programme interventions which can be undertaken.

\section{Points for Programme Managers}

Failure to complete a course of treatment can lead to chronic infections as well as increasing the likelihood of antimicrobial resistance. This can be minimised by:

- Training all health workers to advise people to finish their recommended drug courses

- Simplifying drug courses, for example through the use of single dose regimens 


\section{Public Health Approaches to R'TI/STI Control}

There are a wide variety of factors which put women at risk of endogenous infections
As we have seen, there are three categories of RTI: endogenous infections; sexually transmitted; and iatrogenic. Programme interventions to address these three categories of infection are interlinked and often implemented by the same staff.

\subsection{Control of the Endogenous Infections}

There are a wide variety of factors which put women at risk of endogenous infections (mainly bacterial vaginosis and candidiasis) including, but not limited to:

- Certain types of contraceptive use (including higher dose oral contraceptives)

- Vaginal douching

- Pregnancy

- Use of antibiotics

Control strategies for these infections would include promoting the rational use of antibiotics and use of lower dose oral contraceptives. Other risk factors need to be assessed for the individual woman.

\subsection{Control of Iatrogenic Infections}

Non-sterile procedures across the cervix can result in the upwards transmission of organisms from the lower reproductive tract into the upper tract. In order to prevent this, the following steps should be promoted:

- Care seeking from skilled and qualified health workers

- Screening for infections before undertaking a transcervical instrumentation

- Advising the client to return immediately if there are any abnormal symptoms following such a procedure 


\subsection{Control of the Sexually Transmitted Infections}

The principle steps in achieving STI prevention and care are illustrated in the 'inverse pyramid' model of Piot and Fransen. This has been adapted for Figure 1. This model highlights the areas where STI prevention and care programmes should target efforts to reach greater numbers of infected men and women. Some of the issues and areas addressed in the following sections apply to other RTIs as well as the STIs

Figure 1

Suggested programme level interventions for STI control

Whole community

Primary prevention

Mass treatment options

Vaccination programmes

Prophylaxis against infection

Number of people infected in community

Raise awareness of asymptomatic infections

Screening programmes

Number aware of infection

Improve health care seeking procedures

\section{Number seeking health care}

Improve case management procedures

\section{Number correctly dignosed}

Improve partner management

Improve patient adherence

\section{Number correctly managed}

Appropriate drug regimens used

Antimicrobial resistance patterns known

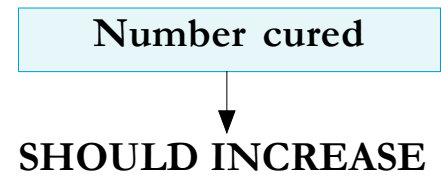


In the following sections, we will concentrate on the first two steps outlined in Figure 1 i.e. public health interventions. The remaining steps have been explored in detail in Section 6 .

\subsection{Behaviour Change Communications for RTIs/STIs}

It has been well substantiated by behavioural scientists that real, long-lasting behaviour change is not the result of simply telling people what to do. Programmes - that tell people 'AIDS Kills; Use a Condom', or 'A Small Family is a Happy Family' will only

\section{Box 3}

\section{Behaviour Change}

It has been well substantiated by behavioural scientists that real, long-lasting behaviour change is not the result of simply telling people what to do
Sustained behaviour change occurs after an individual has moved through various stages described below:

$\underline{\text { Stages of behaviour change }}$

An individual.....

is unaware of problem

becomes aware of problem

is concerned that behaviour places him or her at risk.

acquires knowledge about the problem

is motivated to act through perceived risks and benefits.

is ready for action through skills acquired to enact change

tries new behaviour

assesses the efficacy of changing behaviour and, if successful sustains behaviour change.

To summarise, in order for their behaviour to change, individuals must perceive the following:

- They are at personal risk

- Changing their behaviour will result in benefits that are relevant to them

- Social norms will support their actions at each stage of behavioural change

- They have the skills and resources needed to make the changes. 
be effective if the message is understood by the clients, seen as beneficial, and in accordance with their needs and values.

Communications that do not follow this basic premise are rarely, if ever, effective in achieving behaviour change objective.

To be successful and effective, communication programmes must be based on behaviour change theory, sound public health practice, and well-designed audience assessment combined with innovative communication strategies. Above all, the complex tasks of addressing an issue as sensitive as RTIs/STIs and promoting changes in behaviour that are often deeply ingrained and personal must be approached with a comprehensive, systematic plan that maximises impact.

Behaviour change communications involve understanding the individual's needs, concerns, and perceptions and therefore successful communications programmes must pay attention to:

- Behavioural objectives

- Identifying the audience

- Message development and appropriateness for each audience

- Channels of communication/sources

- Evaluation and feedback

\section{Behavioural Objectives}

These include:

- A change in knowledge, behaviour or attitude

- A change in knowledge about STI/RTI, causation, transmission, prevention or treatment

- Increase in the number of trained counsellors or workers skilled in communication

- Increased condom use or access 
Target audiences are groups of people who have common characteristics related to disease prevention and control
- Abstinence or condom use during the treatment duration

- Fewer repeat STI cases

- Improved STI/RTI referrals or partner notification and/or management

- Reduced incidence of unsafe deliveries, abortions or other trans- cervical procedures

\section{Identifying the Target Audience}

Target audiences are groups of people who have common characteristics related to disease prevention and control. These could be primary or intermediary audiences. Targeted primary audiences may include groups such as adolescents, high risk groups, drug users etc. Other groups that could be targeted for STI/HIV/AIDS prevention and control programmes are health workers and teachers who could be the intermediaries to the primary audiences. Segmenting the audiences is useful as messages developed are then relevant to the needs of a particular group.

Group characteristics can be identified on the basis of high-risk behaviour; demographic factors; psycho-graphics; ethnicity, language and sexual orientation; organisational or institutional structures.

Given below are examples of questions that programme planners can ask in order to learn more about the members of a particular target audience:

- What do members of this target audience know about RTIs/ STIs?

- What are their concerns about RTIs/STIs?

- What behaviours put them at risk for RTIs/STIs?

- What do they do to avoid RTIs/STIs? 
- What are the language, literacy and/or cultural barriers?

- What are some of their perceptions about how RTIs/STIs are acquired?

- What are the special needs of this group?

- Who are the leaders or who has influence over this group?

Quantitative research (surveys) and qualitative research (focus group discussions and interviews) can help answer key questions about a target audience. Findings from secondary data sources can also help in arriving at answers to questions posed above.

\section{Developing Key Messages}

Careful attention needs to be paid to message development to ensure that the messages are not misinterpreted or lead to unintended results. The messages chosen should enable the target audience understand the specific benefits of following the health recommendations and changing behaviour.

It is also important to give members of the target audience an opportunity to respond to message concepts, materials and delivery formats before they are finalised.

Focus groups and interviews are effective methods for developing messages and for pre-testing developed communications products and materials.

Some examples of pre-test questions are:

- What is this message telling you?

- Is this important to you? Why or why not?

- Who do you think should hear these messages?

- Which is an appropriate place to display the messages?

- What do you like/dislike about the messages/materials? 


\section{Selecting Channels of Communication}

The choice of communication channels will depend on many factors, including the programme objectives and the target audience's access to and preference for a particular channel. For example, the mass media are very effective in promoting a general understanding of a problem or issue, whereas interpersonal channels are effective in changing specific and individual attitudes and behaviour. The following information channels are suitable for delivering RTI/STI messages:

The mass media are very effective in promoting a general understanding of a problem or issue, whereas interpersonal channels are effective in changing specific and individual attitudes and behaviour
- Mass media including televisions, radio, audio-visuals, newspapers and magazines. Within these formats, messages can be embedded in the story lines of radio, audio-visuals, television, and folk dramas; or RTI/STI awareness can be raised through news story or through clinic advertisements in local magazines/newspaper. For example, an urban-based NGO used a widely-circulated magazine to place advertorials on RTIs.

- Published media including pamphlets, posters, flip charts, displays, models, booklets and audio and video cassettes. Some of these channels are used to provide information (e.g., pamphlets, flip charts), and others are used to remind people of earlier learning and previous decisions (e.g., posters).

- Institutional and interpersonal networks including centres for formal and non-formal education, factories, women's groups, unions, professional associations, social groups, families, etc. Information disseminated through these groups by peer educators or by visiting "health workers" can be very influential in supporting individuals to understand their symptoms and make the necessary behaviour changes.

- Health service delivery systems including counselling and client education (see Box 3) programmes in clinics; HIV 
counselling and testing centres, community based distribution networks can be effective channels through which to deliver RTI/STI information and prevention messages.

- Training programmes for health workers/providers that include IEC material on local terminology; safe delivery guidelines; clean abortion procedures, etc.

- Peer education is an approach that can be considered a channel or an intervention. Information disseminated through peers often has more credibility, immediacy, and impact than through more formal and distant channels. Peer educators have worked successfully among high risk groups such as truck drivers, adolescents, CSWs, men who have sex with men, and among out of school youth, university students, health workers, and teachers.

A programme manager can use several channels to reinforce RTI/STI information and prevention messages. For example, an audio-visual dealing with personal hygiene could be viewed by a group of young women. Following that a group discussion (or role-playing exercise) that provides key information as well as elicits key concerns could be organised.

\section{Evaluating the Programme}

Evaluation is frequently cited at the end of the communication process, but it should be built into the communication programme as it is being designed. Based on key questions, evaluation helps determine whether and how well the project is achieving its goals and objectives. Process evaluation examines the steps involved in implementing the programme. Outcomes describe the immediate effects of the programme such as the knowledge gained and attitudes changed; the short-term behaviour shifts; any policy or other institutional changes. Impact, the most comprehensive evaluation, focuses on the 
Mid-course

corrections can

then be made to

improve the

activities and

increase the

likelihood of their

success long-range effects of the programme (e.g. whether RTI/STI incidence was reduced as a result of the programme).

Some of the following questions can provide important feedback on the programme:

- If individuals are not taking the educational materials provided, the distribution methods should be assessed. Are they left in conspicuous places? Are they available where the key audiences congregate? Should they be distributed personally by the health care providers or by peers? Are people too embarrassed to be seen with them? Would a new design be more appealing or attractive?

- If clients are not coming back for follow-up visits, do the health care providers need more training in counselling, patient education or interpersonal skills?

Answering these questions will give feedback and help identify the project's strengths and weaknesses. Mid-course corrections can then be made to improve the activities and increase the likelihood of their success. Answering such questions early in the project will lead to refinement of the communication strategies and increase the effectiveness of the overall programme.

\section{Points for Programme Managers}

Communication programmes for RTI/STI control and prevention need not rely on expensive materials or the latest in technological innovations to be successful. If properly planned and implemented, communication activities both within and outside the treatment settings can make an important contribution to RTI/STI prevention and control programmes. The programme manager is encouraged to identify and contact local resources. These include advertising or public relations agencies, professional writers and editors, and other communication experts in health departments or non-governmental organizations (NGOs). 
Box 4

\section{Client Education}

Client education centres on behaviour change advising in a clinic setting as a viable approach to encourage a behavioural risk-reduction. Since it is generally accepted that education as informationgiving alone is not a sufficient prevention strategy, education in this context includes motivational messages and approaches to changing behaviour as well as providing factual information. Telling a client how RTIs/STIs are transmitted and how they can be treated may be informational. In client education the session might include an advisory component, such as 'take your pills in the morning; do not take them on an empty stomach; or it is important to discuss symptoms with your partner'. It is different from counselling in that "counselling" is generally accepted by mental health professionals to mean in-depth, long-term and repeated interactions between a trained counselling professional and a client covering topics that can be very broad in scope and emotional in nature. For this reason, the phrase "behaviour change advising" is preferred. This conveys the idea that in a clinic setting, there are usually limited human resources available and the interaction between client and health care worker may be brief as well as restricted to only one encounter.

There are many reasons supporting the use of a clinic visit as an opportunity for client education:

- It is efficient because it reaches the patient where the patient is

- If you can prevent RTIs/STIs, you can prevent associated sequelae

- The time is right. Clients are likely to be motivated to find out how to avoid the same discomfort in the future

- Preventing future visits contributes to the community's overall productivity

- Treatment is more likely to be effective if a client understands the regimen

- Effective client education is part of delivering quality reproductive health care

One aspect of client education that is sufficiently recognised is the potential for a multiplying effect when clients take home information and materials and discuss what they have learned with family members and friends. If the community has an active outreach education program, this clinic-based education can reinforce those efforts.

\section{What the client needs to know}

\section{Recognition and Prevention Measures}

- Physical symptoms (what to look for and what it means)

- Personal hygiene procedures 
Mass treatment is an alternative and more radical approach to reducing the high numbers of people infected with STIs
- Condom use

- Partner communication

- Alternatives to penetrative sex

\section{RTIs}

- Factors causing RTIs

- How RTIs/STIs are passed between people

- Consequences of RTIs

- Relationship of RTIs/STIs and HIV/AIDS

\section{Treatment}

- How to take medicine (with what other substance and for how long)

- Signs that call for a return to the clinic

- Importance of partner referral and treatment

- Abstinence or condom use during the treatment

\subsection{Mass Treatment}

Mass treatment is an alternative and more radical approach to reducing the high numbers of people infected with STIs. Whole communities, or selected populations within communities, are given regular repeated doses of drugs against bacterial infections. Its main advantage is that of addressing infection in asymptomatic individuals. Other benefits include no diagnostic tests needed, a modest training for health workers, and participants can be treated at home. However, mass treatment can be an expensive strategy and repetition of repeated drug doses carries a potential danger of antibiotic resistance both among RTI/STI pathogens. Some experts have also voiced serious doubts about sustainability and long term effectiveness of mass treatment for STIs.

Examples of mass treatment include those conducted in the Rakai District, Uganda, which assessed whether this 
intervention resulted in reduced HIV incidence. Mass treatment was offered to all subjects in the intervention arm, whether symptomatic or not, and independent of laboratory testing (except for syphilis). HIV incidence was equivalent in both arms of the study - indicating that this approach did not work in this community. Other mass campaigns in pursuit of the eradication of syphilis in Bosnia-Herzegovina (1948-1955), in Indonesia (1958-1982) and in China (in the 1960s) were more successful. More recent examples of mass treatment being used with success are found in programmes which have undertaken 'targeted mass treatment'. For example, in the mining towns of South Africa, interventions giving mass treatment to sex workers resulted in a concomitant fall in the number of new infections in the miners, their main client group.

\subsection{Vaccination Programmes}

There are no vaccinations currently available against sexually transmitted infections or the endogenous infections. However, there is an effective vaccine against hepatitis $B-a$ virus which can be sexually transmitted, but which is most often acquired through materno-fetal infection or childhood transmission in endemic countries. The recommended schedule for control of hepatitis $B$ is to add the vaccine into the routine childhood vaccination programme - this approach has been recommended for India.

\subsection{Prophylaxis Against Infection}

Prophylaxis is only recommended for one preventable condition: ophthalmia neonatorum $(\mathrm{ON})$. This is a potentially sight-threatening eye infection in infants, due to Neisseria gonorrhoeae or Chlamydia trachomatis transmitted from the mother at the time of delivery.

Strategies for the control of $\mathrm{ON}$ include:

(a) preventing infection in the mother, 
ON prophylaxis is both cheap and simple to administer (b) treating infected pregnant women before they give birth;

(c) managing individual cases of infection in neonates; and

(d) prophylaxis in all neonates at birth.

Whilst the first of these four options remains the ultimate goal of most STI control programmes, programme managers are currently faced with the question of how to manage or prevent infection in infants. This situation arises in part because the possibility of screening all pregnant women before birth and finding all those who are infected remains low.

Thus, the choice for most programmes will be between case management of infected infants, or ocular prophylaxis of all infants. Active case management of a child with gonococcal or chlamydial ophthalmic infection generally presents a much larger challenge to the health-care system. Correct management of the neonate ultimately relies on the parents/carers seeking treatment from a trained provider who can correctly diagnose and manage $\mathrm{ON}$. It is felt that this assumption is too great a risk to take when the possibility of preventing infection in the first place is both simple and inexpensive.

ON prophylaxis is both cheap and simple to administer. The choice of regimen will depend on the local cost of the drugs, the incidence of ON (both commonly used drugs have some degree of failure - higher for silver nitrate than for tetracycline), and the ability of health care personnel to correctly manage the storage and handling of the drugs (especially silver nitrate) in order to minimise the likelihood of chemical conjunctivitis. Given that ON prophylaxis should be administered within the first few hours after birth, it is clear that any programme to prevent $\mathrm{ON}$ through the use of topical prophylaxis will be dependent upon adequate training of those most likely to be involved in the delivery of infants. 


\subsection{Raise Awareness of Asymptomatic Infections}

Whilst there are many published studies on the prevalence of asymptomatic infections in communities, there are unfortunately few working programmes addressing this issue. The sexually transmitted infections, chlamydia and gonorrhoea, have been found to be carried asymptomatically in a majority (over 50\%) of infected men and women. Syphilis only causes symptoms for a short period of time and then enters a latent phase when it can only be detected through blood testing although it is still potentially harmful to the infected individual and her unborn child. This clearly creates a problem in designing appropriate programme responses. In the absence of widespread screening facilities, individuals who are infected but asymptomatic must be reached through a variety of other strategies. These might include:

- Partner management

- IEC campaigns persuading people who believe themselves to be at risk of infection to attend for a genital health check-up

- Training health workers to consider the possibility of asymptomatic infection in people seeking care for other services - i.e. case finding. This approach relies upon having screening facilities available in the health services.

Prophylactic use of antibiotics in people thought to be 'at risk' but not the partners of known-to-be-infected persons, is not recommended.

\subsection{Screening Programmes}

Case finding is a process of opportunistic screening for an infection at a time that an individual presents to a health facility regardless of the presence of symptoms. Case finding among family planning clients is an important opportunity to detect and counsel about these infections when women and men present for contraceptive services. 
The cost of syphilis screening is low and the diagnostic technology is simple to use
Screening usually implies wider coverage and attempts to identify an infection in a (whole) population which does not usually access services. Widespread screening strategies for the common STIs (chlamydia and gonorrhoea) are unlikely to be feasible in resource poor settings. However, there are situations when screening should be considered - for example among antenatal clinic attendees, when the benefits of screening are clear.

The most common screening programmes worldwide are those for detecting syphilis in pregnant women. Untreated syphilis in pregnancy is associated with a number of adverse outcomes: pregnancy loss; stillbirth; congenital syphilis. It is estimated that only one third of pregnancies in mothers with untreated syphilis will result in a normal healthy baby. A further third will end in spontaneous abortion or neonatal death, and the remaining third will produce children with congenital syphilis. Such a high rate of materno-fetal transmission, the severe physical, mental and emotional consequences of congenital syphilis, combined with the relative ease, high sensitivity and specificity, and low cost of both screening and treatment, have established screening programmes as a cornerstone of syphilis control.

The cost of syphilis screening is low and the diagnostic technology is simple to use. Similarly, the cost of treatment for each serologically reactive woman is also low. It has been shown that even when the prevalence of syphilis is as low as 1 in 1000 , screening pregnant women is still a cost-effective intervention compared with not screening and treating women at all. Screening programmes for syphilis rely upon the use of simple, inexpensive tests (most usually rapid plasma reagin, RPR, or Venereal Disease Research Laboratory, VDRL) which can be undertaken at the PHC level. Treatment is then administered to any woman with reactive serology and she is encouraged to bring her partner in for treatment. Whilst there is a possibility of 
a low level of overtreatment if only screening test results are used, (due to the lower specificity of RPR or VDRL compared to the confirmatory test) this is usually outweighed by the benefit of treating a woman immediately instead of asking her to return, collect results and then undergo treatment.

\subsection{Which Interventions Should Programme Managers Use?}

As we have seen above, there are a number of effective interventions which can be incorporated into RTI/STI control programmes. It is important to remember that priorities for programme interventions are often set according to economic priorities - usually because these are among the easiest variables to measure, and because programmes have to be financially accountable. In the case of RTIs, this often leads to a focus on the control of the sexually transmitted infections because they are more likely to have serious outcomes and sequelae. Nonetheless, the endogenous infections are often more common, especially in women, and effective management of these infections should not be overlooked.

For programmes to be appropriate and effective, it is important to consider other factors in addition to the economic ones. The exact mix of interventions chosen should depend upon the prevailing social, cultural, political, economic and logistical factors prevalent locally and should be targeted to the local epidemiology and aetiology of common RTIs/STIs. In other words, in order to design appropriate and effective programmes it is important to have some knowledge of the infections which are being targeted, and the groups most at risk for each type of infection. Programme managers can then decide which of the known-to-be-effective interventions are most appropriate for their particular setting. In making these choices, Table 4 aims to guide programme managers in looking at the range of possible 
interventions which may be appropriate in their particular setting. There may be some interventions which are critical and should be implemented immediately, whilst others may need more information, assessment and planning. Examples of the former may include screening pregnant women for syphilis, whilst the latter might include programmes to change health

Table 4

\section{Prioritising programme interventions}

a) Symptomatic Individuals

\begin{tabular}{|l|l|l|l|l|l|l|l|}
\hline Intervention & $\begin{array}{l}\text { Sexually } \\
\text { Active } \\
\text { Men }\end{array}$ & $\begin{array}{l}\text { Sexually } \\
\text { Active } \\
\text { Women }\end{array}$ & $\begin{array}{l}\text { Pregnant } \\
\text { Women }\end{array}$ & $\begin{array}{l}\text { Family } \\
\text { Planning } \\
\text { Clients }\end{array}$ & $\begin{array}{l}\text { Infants } \\
\text { Groups } \\
\text { Requiring } \\
\text { Targeted } \\
\text { Inter- } \\
\text { ventions }\end{array}$ & $\begin{array}{l}\text { 'Vulnerable } \\
\text { Groups' }\end{array}$ \\
\hline $\begin{array}{l}\text { 1. Encourage } \\
\text { appropriate and } \\
\text { prompt care } \\
\text { seeking behaviour }\end{array}$ & & & & & & & \\
\hline $\begin{array}{l}\text { 2. Standardise case } \\
\text { management }\end{array}$ & & & & & & & \\
\hline $\begin{array}{l}\text { 3. Improve treatment } \\
\text { adherence and } \\
\text { abstinence during } \\
\text { treatment }\end{array}$ & & & & & & \\
\hline $\begin{array}{l}\text { 4. Clinic-based } \\
\text { counselling for } \\
\text { prevention } \\
\text { including condom } \\
\text { promotion and } \\
\text { voluntary } \\
\text { counselling and } \\
\text { testing) }\end{array}$ & & & & & & \\
\hline
\end{tabular}


seeking behaviour. Table 4 can be used to plan interventions which might be appropriate in the short, medium and longer terms.

The table is not a blueprint for programme design, it merely serves to emphasise that there are a number of 'target' audiences to be considered, and a wide variety of interventions that may be appropriate and effective in addressing the management of established RTIs among these infected women and men.

b) Asymptomatic Individuals

\begin{tabular}{|l|l|l|l|l|l|l|l|}
\hline Intervention & $\begin{array}{l}\text { Sexually } \\
\text { Active } \\
\text { Men }\end{array}$ & $\begin{array}{l}\text { Sexually } \\
\text { Active } \\
\text { Women }\end{array}$ & $\begin{array}{l}\text { Pregnant } \\
\text { Women }\end{array}$ & $\begin{array}{l}\text { Family } \\
\text { Planning } \\
\text { Clients }\end{array}$ & Infants & $\begin{array}{l}\text { Groups } \\
\text { Requiring } \\
\text { Targeted } \\
\text { Inter- } \\
\text { ventions }\end{array}$ & $\begin{array}{l}\text { 'Vulnerable } \\
\text { Groups' }\end{array}$ \\
\hline $\begin{array}{l}\text { 1. Mass } \\
\text { screening }\end{array}$ & & & & & & & \\
\hline $\begin{array}{l}\text { 2. Selective } \\
\text { screening }\end{array}$ & & & & & & & \\
\hline $\begin{array}{l}\text { 3. Partner } \\
\text { referral } \\
\text { and } \\
\text { treatment }\end{array}$ & & & & & & & \\
\hline $\begin{array}{c}\text { 4. Presumptive } \\
\text { treatment }\end{array}$ & & & & & & & \\
\hline
\end{tabular}

Notes on Table: Each box requires a programmatic decision concerning the appropriate action to pursue. Many of the boxes will not require any decisions to be made. For example, the appropriate programme response for infants will usually be Presumptive Treatment (ON prophylaxis) and all other boxes will remain blank. Similarly, pregnant women should be offered mass screening for syphilis. Other interventions will depend upon the particular local context, taking into account the range of contributing factors as discussed.

Groups which may require targeted interventions include those known or perceived to be at higher risk of infection. Examples may include commercial sex workers and their clients. Vulnerable groups may not necessarily have higher rates of infection, but may be potentially exposed to risk. Examples might include adolescents and migrant workers. 
The endogenous and iatrogenic infections are found predominantly among women

\section{Points for Programme Managers}

The highest public health priority is for primary prevention of infection. Primary prevention efforts are not $100 \%$ successful, however, resulting in a need for additional interventions to address the problem of established infections of the reproductive tract. A comprehensive mix of interventions should focus on: enhanced symptom recognition and appropriate health care seeking behaviour; screening (e.g. for cervical cancer, or among pregnant women for syphilis); prophylaxis (e.g. against ophthalmia neonatorum); vaccination (e.g. against hepatitis B); effective outreach programmes to identify symptomatic men and their sexual partners; and improved quality of clinical services for women and men. The appropriate mix of interventions for each local and/or national programme is determined by a number of inter-related factors:

- Prevalence and incidence of RTIs

- Cultural and social norms of sexual and health behaviours

- Patterns of health care seeking behaviour including use of public and private health services

- Resources available at country level including structure of public health programmes

- Patterns of antimicrobial use and resistance

\subsection{A Gender-based Perspective on RTI Programmes}

The endogenous and iatrogenic infections are found predominantly among women, and women are the usual focus of public health programmes for the control of these infections. In the case of the STIs, programmatic focus must include comprehensive interventions for both men and women.

Sexually transmitted infections, including HIV, are more easily transmitted from men to women than women to men. Studies 
have shown that women are twice as likely to become infected by a variety of sexually transmitted pathogens (this may be higher in the case of HIV). In addition, in societies where gender inequities are strong (such as some parts of India) women may be at greater risk of acquiring sexually transmitted infections from men owing to social or cultural norms of behaviour which preclude women the ability to refuse sexual intercourse with their partners or to insist upon the use of barrier methods of protection. Once a woman is infected with an STI, treatment options available to her can be limited by a number of factors:

- Her ability to seek care from trained and qualified providers (Can she leave home without permission? Can she afford effective treatment? etc.)

- The high rate of asymptomatic carriage of the infecting organisms

- The relatively poor performance of the syndromic diagnostic and treatment interventions recommended for women with complaints of vaginal discharge

- The power imbalances in many heterosexual relationships which reduce the ability of women to inform their partners if they have an STI, and to protect themselves from reinfection.

Moreover, once a woman is infected with a sexually transmitted infection, she has a higher chance that infection will result in an acute or chronic complication (such as pelvic inflammatory disease, chronic pain, infertility, cervical cancer or transmission to an unborn child) than the equivalent infections in men.

To address these issues, programmes should be aware of and respond to the biological, economic and social vulnerabilities to RTI/STI transmission which are predominantly found in women. This does not, however, mean that programmes should be

In societies where gender inequities are strong (such as some parts of India) women may be at greater risk of acquiring sexually transmitted infections from men owing to social or cultural norms of behaviour 
There is a strong argument for ensuring that STI services for men are also strengthened focussed only on women. Indeed, given the fact that men are usually more at risk of contracting STIs outside the home, and that they are also more likely to have specific symptoms and possibly to seek care, there is a strong argument for ensuring that STI services for men are also strengthened in the hope that they will be both management and prevention services.

\section{Points for Programme Managers}

Women are more at risk of all types of RTIs. In addition, social and cultural factors often inhibit women's ability to protect themselves from infection, or even to seek care once infected. Nonetheless, in order to be effective, STI control programmes must address the needs of both men and women.

\subsection{Sources of Data for Programme Managers}

Typically, programme managers have imperfect data on many or all of the factors mentioned in section 7.7. Under these circumstances, the ability to make decisions on what constitute effective interventions that should be included in a comprehensive public health programme is often severely hampered. Nonetheless, there are basic principles guiding programme design, and these can be followed for RTI/STI programmes. These principles include:

- Knowledge of burden of disease

- The effectiveness of 'technical' solutions

- The cost-effectiveness of these solutions

In this document we have explored the first two principles in relation to India - knowledge of the burden of disease in different populations has been outlined (sections $2.2 \& 2.3$ ), and the effectiveness of different 'technical solutions' was explored in section 6.2. Evidence on the cost-effectiveness of different interventions is mainly undocumented in the Indian context, 
leaving programme managers to make decisions predominantly on the basis of burden of disease and available interventions.

Throughout this document we have stressed the importance of knowing the local epidemiology and aetiology of the infections to be targeted. It is clear, however, that in many instances this information will not be available at a local level. In such cases, there are several alternative options for determining local epidemiology:

- Rapid situational assessments with primary and secondary stakeholders

- Secondary data sources (such as records on admissions for PID)

- Cross-sectional surveys conducted by local researchers/ NGOs etc

- Knowledge of the existence and size of groups at higher risk of STIs in the target community

- Data from local sentinel surveillance for HIV/AIDS

- Medical college data on RTI/STI patients

These sources of information can be used to provide a 'guesstimate' of the prevalence of STIs/RTIs when active or passive surveillance is not available to inform programme design.

\section{Points for Programme Managers}

For programmes to be effective, they must be tailored to the local epidemiology and aetiology of the infections they are aiming to control. Surveillance systems provide the 'gold standard' of evidence as they allow programme managers to monitor trends with time. In the absence of surveillance systems, programme managers should look for alternative sources of data to inform their decision-making. 


\section{Programme Monitoring}

Setting objectives allows programme managers to determine what types of information they will need to collect as the programme proceeds
Basic principles of programme monitoring are included below, but further details can be found in some of the references mentioned in the bibliography.

Once programme managers have decided upon the most appropriate mix of interventions for their own epidemiological and aetiological situation, how can they monitor the programme with regards to effectiveness and impact? The first step must be to decide upon the aims and objectives of the programme itself. Setting objectives allows programme managers to determine what types of information they will need to collect as the programme proceeds. The key to data collection activities is to ensure that data are both useful and utilised. In addition, feedback of results helps staff to see the purpose of data collection and may increase their willingness to collect meaningful and high quality data.

Monitoring activities should concentrate at least on the following parameters:

- Operational aspects of service delivery (e.g. client numbers; diagnoses made; drugs distributed; condoms provided)

- Staff and personal issues (e.g. proportion of staff who have been adequately trained; supervision of staff)

- Client satisfaction (e.g. how many visits are repeat or follow-up?)

- Costs

- Issues of quality of care - including partner management, reinfection rates, referral rates, and management of side-effects. 
In addition to these activities, WHO has developed a series of Programme Indicators that can be used for periodic monitoring of programmes. Further information can be found in the bibliography section.

\section{Points for Programme Managers}

Data collection activities are integral to ensuring the efficient and effective running of services. Programme monitoring should be based upon agreed objectives, and the flow of useful data should be bi-directional. 


\section{References and Suggested Bibliogiaphy}

Aggarwal, R. and Naik, S. R. 1994. Prevention of hepatitis B infection: The appropriate strategy for India. National Medical Journal of India $7(5): 216-220$

Dallabetta, G., Laga, M. and Lamptey, P. (eds).1986 Control of Sexually Transmitted Diseases: A Handbook for the Design and Management of Programmes. Arlington Virginia, USA: AIDSCAP/Family Health International.

Elias, C. J. 1994. A puzzle of will: Responding to RTIs in the context of family planning programmes. In: Critical Issues in Reproductive Health: Reproductive Health Approach to Family Planning. New York. The Population Council.

Hawkes S., Santhya K. G. 2001. Diverse Realities: Understanding STIs and HIV in India. Regional Working Paper no. 15. New Delhi: Population Council.

Hawkes S and Hart G. Reproductive health: Men's roles and men's rights. In: Jejeebhoy S, Keonig, M. and Shah, I. (eds)., Undertaking Community Surveys of Gynaecological Morbidity Cambridge University Press, forthcoming.

Irwig, L., Zwarenstein, M., Zwi, A. B., and Chalmers, I. 1998 A flow diagram to facilitate selection of interventions and research for health care. Bulletin WHO 76 (10):17-24.

Mertens, T., Carael, M., Sato, P. et al. 1994. Prevention indicators for evaluating the progress of national AIDS programmes, AIDS 8 (suppl 1):S359-369. 
Nataraj, S. 1994. Waiting for a connection. Populi 21(10):6-11

Over, M. and Piot, P. 1993. HIV infection and sexually transmitted diseases. In: Jamison, D. T. et al (eds)., Disease Control Priorities in Developing Countries. New York: Oxford University Press.

Raju, S. and Leonard, A. 2000. Men as supportive partners in reproductive health: Moving from rhetoric to reality. Population Council. New Delhi.

Regional Annual Report. 2000. South and East Asia Region. New Delhi: Population Council.

United Nations. 1994. Programme of Action of the UN International Conference on Population and Development. New York: United Nations.

Van Dam, C. J. 1995. HIV, STD and their current impact on reproductive health: The need for control of sexually transmitted diseases. International Journal of Gynaecology and Obstetrics (Suppl 2): S121-S129.

Wasserheit, J. N. 1989. The significance and scope of RTIs among third world women. International Journal of Gynecology and Obstetrics (Suppl 3):145-168.

Wasserheit, J. N. and Holmes, K. K. 1992. RTIs: Challenges for international health policy, programmes and research. In: Germain, A., Holmes, K. K., Piot, P. and Wasserheit, J. N. (eds)., Reproductive Tract Infections, New York: Plenum Press.

World Health Organization. 1994. Evaluation of a national programme: A methods package 1. Prevention of HIV infection. Geneva.

World Health Organization/Global Programme on AIDS. 1995. Global Prevalence and Incidence of Selected Curable Sexually Transmitted Diseases: Overview and Estimates, WHO/GPA/STD 95.1 


\section{Aninex}

\section{Estimated No. of RTI Cases and Per Episode Cost for Drug Therapy}

\section{An Estimate for India:}

\begin{tabular}{|ll|c|}
\hline 1. & Estimated number of eligible couples (15-45 years) per 1,00,000 population & 17,000 \\
\hline 2. & $\begin{array}{l}\text { Estimated number of women reporting RTIs symptomatics only } \\
\text { (30 per cent) }\end{array}$ & 5,100 \\
\hline $\begin{array}{l}\text { 3. } \\
\text { Estimated number of women who will be seeking treatment from } \\
\text { government health facility in the absence of intensive IEC efforts (25 per } \\
\text { cent of } 2 \text { above) }\end{array}$ & 1,275 \\
\hline 4. & $\begin{array}{l}\text { Considering } 65^{*} \text { per cent RTIs to be associated with sexual mode of } \\
\text { transmission, partners to be covered for treatment }\end{array}$ & 828 \\
\hline
\end{tabular}

\begin{tabular}{|c|c|c|c|c|c|c|}
\hline S. No. & $\begin{array}{l}\text { Distribution } \\
\text { of morbidity }\end{array}$ & Proportion & $\begin{array}{l}\text { Est. no. of } \\
\text { episodes }\end{array}$ & $\begin{array}{c}\text { Unit Cost } \\
\text { per episode in Rs. }\end{array}$ & $\begin{array}{c}\text { Total } \\
\text { cost in Rs. }\end{array}$ & $\begin{array}{l}\text { Drug } \\
\text { regimen }\end{array}$ \\
\hline 1 & Syphilis & $7 \%$ & 176 & 21.00 & 2,646 & $\begin{array}{l}\text { Benzathin } \\
\text { Penicilline, } \\
\text { Long Actg } 24\end{array}$ \\
\hline 2 & Gonorrhoea & $3 \%$ & 76 & 9.00 & 450 & $\begin{array}{l}\text { Norfloxacin } \\
\text { 800mg single dose }\end{array}$ \\
\hline 3 & Trichomoniasis & $20 \%$ & 510 & 4.00 & 2,040 & $\begin{array}{l}\text { Metronidazole } \\
\text { 400mg } 5 \text { tabs }\end{array}$ \\
\hline 4 & Candidiasis & $25 \%$ & \begin{tabular}{|c|}
318 (women) \\
159 (men), \\
assuming $50 \%$ \\
sexual \\
transmission
\end{tabular} & $\begin{array}{r}7.00 \\
30.00\end{array}$ & $\begin{array}{l}2,226 \\
4,770\end{array}$ & $\begin{array}{l}\text { Clotrimazole } \\
500 \text { mg Intra } \\
\text { vaginal tab } \\
\text { Fluconazole } \\
150 \mathrm{mg} 1 \text { tab stat }\end{array}$ \\
\hline 5 & $\begin{array}{l}\text { Bacterial } \\
\text { Vaginoisis }\end{array}$ & $35 \%$ & 450 & 4.00 & 1,800 & $\begin{array}{l}\text { Metronidazole } \\
\text { 400mg } 5 \text { tabs }\end{array}$ \\
\hline 6 & Chlamydia & $10 \%$ & 254 & 42.00 & 10,668 & $\begin{array}{l}\text { Cap. Doxicyclline } \\
\text { 100mg } 1 \text { BD for } \\
7 \text { days }\end{array}$ \\
\hline
\end{tabular}

* In high prevalence settings. These estimates will vary considerably depending on patterns of etilogical diagnosis for RTIs in the area 
This document is not a formal publication of the UNFPA or the Population Council. Views expressed in the document are those of the authors.

This document may be freely reviewed, reproduced or translated, but not for commercial purposes. An intimation of the above to the publishers will be appreciated.

UNFPA and Population Council

New Delhi, India

2001

Design : Mensa Computers Pvt. Ltd., mensa@vsnl.com 


\section{Table of Contents}

Foreword v

Acknowledgements vi

List of Acronyms vii

1 What are Reproductive Tract Infections? 1

2 Epidemiology of RTIs/STIs 3

2.1 Epidemiology of RTIs/STIs Globally 3

2.2 Epidemiology of RTIs/STIs in India 3

2.3 Epidemiology Diversity in India 6

3 Why Aim to Control Reproductive Tract Infections 9 and Sexually Transmitted Infections?

4 Clinical Presentation of RTIs 12

4.1 Main Clinical Complications of RTIs 12

5 The Diagnosis of RTIs 14

6 Prevention and Care of RTIs 18

6.1 Promoting Effective Health Care Seeking 18

6.2 Case Management of Symptomatic Individuals 19

6.3 Partner Management 21

6.4 Counselling for Prevention 24

6.5 Improving Treatment Adherence 25

7 Public Health Approaches to RTI/STI Control 26

7.1 Control of the Endogenous Infections 26

7.2 Control of Iatrogenic Infections 26 
7.3 Control of the Sexually Transmitted Infections 27

7.4 Behaviour Change Communications for RTIS/STIs 28

7.5 Mass Treatment 36

7.6 Vaccination Programmes 37

7.7 Prophylaxis Against Infection 37

7.8 Raise Awareness of Asymptomatic Infections 39

7.9 Screening Programmes 39

7.10 Which Interventions Should Programme Managers Use? 41

7.11 A Gender-based Perspective on RTI Programmes 44

7.12 Sources of Data for Programme Managers 46

8 Programme Monitoring 48

9 Suggested Bibliography 5

10 Annex 52 


\section{Foreword}

Reproductive tract infections including sexually transmitted infections represent a silent worldwide pandemic, which adversely impacts reproductive health of women and men. Various community and hospital based studies in India have provided insights into the magnitude of the problem.

The International Conference on Population and Development (1994), emphasised integration of reproductive health services to meet the needs of men and women especially with reference to prevention and management of RTIs/STIs. The emergence of HIV and the identification of STIs as a risk factor for the spread of HIV have further lent a sense of urgency for a programmatic response to address this important public health problem.

Programmatic evidence from developing countries indicates that integration of RTIs/STIs prevention and management with existing health services is both feasible and cost effective. The National Population Policy - 2000 also highlights the need for programmes, which include provision of RTI/STI and HIV/AIDS prevention, screening and management in reproductive health care settings. Appropriately designed, primary prevention and case management interventions would contribute significantly in reducing the burden of the disease and improving the quality of life.

The last decade is witness to major advances in the programming for RTI/STI prevention and management interventions. Depending on the magnitude of the problem and maturity of the programmes, variety of the approaches are being suggested. The present guide reviews available global and regional experiences and provides strategic directions, which are likely to be the most effective in addressing these problems in India.

The need for a concise information on different components of the programmatic response to meet this challenge has been articulated at several levels. The present publication is an attempt to fulfill such information gaps, that constitute a major constraint in designing appropriate interventions. We sincerely hope that programme managers and service providers will find this information useful. The efforts of Population Council, South and East Asia Regional Office are appreciated for putting together evidence based information in this publication.

November 2001

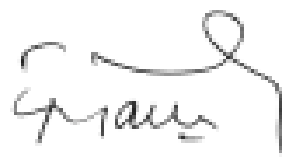

Francois M. Farah UNFPA Representative 


\section{Acknowledgements}

Many of the ideas and information in this booklet were developed as part of an ongoing collaboration between the Population Council's Horizons Project and the World Health Organization.

We have benefited greatly (in Sections 5 and 8) from the following book: Dallabetta, G., Laga, M., and Lamptey, P. (eds.). 1996. Control of Sexually Transmitted Diseases: A Handbook for the Design and Management of Programmes. AIDSCAP/Family Health International, Arlington Virginia, USA.

Table 3 on page 16 is adapted from this book, with the permission of Family Health International (FHI). We would like to acknowledge the debt we owe to the authors and editors of this seminal publication. Any errors in this work are entirely our own.

We would also like to thank JHPIEGO (International Education and Training in Reproductive Health - an affiliate of Johns Hopkins University) for permission to use the clinical and microbiological slides reproduced on pages 22 and 23.

Finally, many thanks to Jyoti Bahri for her copy editing. 


\section{List of Acronyms}

CT Chlamydia trachomatis

DFA Direct Fluorescent Antibody Test

ELISA Enzyme Linked Immunosorbent Assay

FTA Fluorescent Treponemal Antibody

GC Neisseria gonorrhoeae

HbsAg Hepatitis B Surface Antigen

HBV Hepatitis B Virus

HIV Human Immunodeficiency Virus

HPV Human Papilloma Virus

HSV Herpes Simplex Virus

ICPD International Conference on Population and Development

IEC Information, Education \& Communication

IgM Immunoglobulin $\mathrm{M}$

IUD Intrauterine Devices

$\mathrm{KOH} \quad$ Potassium Hydroxide

NACO National AIDS Control Organization

NGO Non-Government Organization

ON Ophthalmia Neonatorum

OPD Out Patient Department

PCR Polymerase Chain Reaction

PHC Primary Health Care

PID Pelvic Inflammatory Disease

PM Partner Management 


$\begin{array}{ll}\text { RCH } & \text { Reproductive and Child Health } \\ \text { RH } & \text { Reproductive Health } \\ \text { RPR } & \text { Rapid Plasma Reagin } \\ \text { RTI } & \text { Reproductive Tract Infection } \\ \text { STD } & \text { Sexually Transmitted Disease } \\ \text { STI } & \text { Sexually Transmitted Infection } \\ \text { SW } & \text { Sex Workers } \\ \text { TPHA } & \text { Treponema Pallidum Haemagglutination Assay } \\ \text { TV } & \text { Trichomonas Vaginalis } \\ \text { VDRL } & \text { Venereal Disease Research Laboratory } \\ \text { WHO } & \text { World Health Organisation }\end{array}$

